\title{
Human Rights Violation and Political Persecution in Bangladesh:
}

\section{The Current Scenery}

\author{
Dr. Md. Abdul Jalil \\ Associate Professor \\ Department of Business Administration, Faculty of Economics and Management \\ International Islamic University Malaysia, Malaysia \\ E-mail: abd_jalil2@yahoo.com, abduljalil@iium.edu.my \\ Muhammad Khalilur Rahman \\ Department of Business Administration, Faculty of Economics and Management \\ International Islamic University Malaysia, Malaysia \\ E-mail: abd_khalil2@yahoo.com
}

\begin{abstract}
Bangladesh emerged as an independent country in the South Asia in 1971 after being separated from Pakistan. In 1971 it was a very poor country. The general people had a hope and dream that the political parties will develop the country and will eradicate poverty gradually, will provide jobs to the $50 \%$ unemployed people, will educate the $60 \%$ illiterate people; but their holy hope and dream have not been fulfilled due to frequent hostile political culture, beating, killing among the political party members, no patriotism among the political leaders, massive corruption, unnecessary frequent strike, unnecessary opposition to the government policy etc. This paper has narrated the past and current social and political situation in Bangladesh briefly with the help of data collected from newspapers and statements given by intellectuals and political leaders. Descriptive and analytical research methodology has been applied in this paper to narrate the situation.
\end{abstract}

Keywords: Human rights, Human rights violation, Constitutional right, Right to fair trial, Democratic right, Political persecution

\section{Introduction}

Bangladesh is a poor country in southern Asia. It locates southern side of India and above the Bay of Bengal. It is a very small country but it has large population, 150 million. It was a part of Pakistan and was separated as an independent country in 1971 through 9 months bloody liberation war. Thousands of people died in this liberation movement against the government of Pakistan. At that time, some political parties thought it would not be for the interest of Bangladeshi people to separate Bangladesh from Pakistan as India wanted to divide Pakistan into two parts to gain its own political and imperialistic policy. Therefore, more than 6 political parties including Bangladesh Jamaat-e-Islami (BJI or better known as Jamaat), Muslim League, Nejame Islami, Pro-China Communist Party etc. opposed the separation movement of Bangladesh from Pakistan. Besides, thousand of scholars and intellectuals who were not involved in any political party also sincerely opposed the separation of Bangladesh from Pakistan as they thought separating Bangladesh with the help of India might not be beneficial for the future of Bangladeshi people.

Anyhow, Bangladesh became an independent country on 16 December 1971 after the Pakistani army surrendered to the Chief of Indian military forces. After independence of Bangladesh, BJI supporters (around 100,000 at that time) accepted the independence of Bangladesh happily and worked for the development of Bangladesh and did not do anything which may go against the interest and independence of Bangladesh. It did not keep any relation with Pakistan government afterwards. This is a historically proven fact. It is alleged by the pro-independence force in Bangladesh for example Awami League (AL) that Jamaat was involved in war crimes during 1971. However, Jamaat leaders in different occasions for the last 39 years vehemently claimed that they opposed separation of Pakistan peacefully but they were never involved in any killing, rape or arson cases. Their claim is strengthened by the fact that until 2009 there was no murder, rape, looting or arson case had been filed against any Jamaat leaders and its supporters by any person in any police station in Bangladesh. In 2009 and 
2010 some war crimes and murder cases have been filed in different police station by AL members by the instruction of AL government. So, these are false cases and totally politically motivated. These cases are completely baseless.

The objective of this paper is to briefly narrate the hostile social and political cultural history of Bangladesh since 1971 and what is happening currently under the leadership of the present autocratic regime. Descriptive and analytical research methodology has been applied in this research. Data has been collected from newspapers, journals and interviews of high profile scholars, politicians and intellectuals.

\section{Nature of Contemporary Political Culture in Bangladesh and Violation of Human Rights}

As stated earlier, Pakistan was formed from India in 1947 through long struggle and sacrifice of many people against the rule of English people. English people ruled Indian subcontinent for around two hundred years. First they came to India to do business in the name of 'East India Company' and later they occupied the political power of whole Indian subcontinent gradually. In 1947 Pakistan was formed being separated from India which was one country at that time. Pakistan had two parts: i) West Pakistan and ii) East Pakistan. East Pakistan is now known as Bangladesh and it became separated from Pakistan in 1971. The West Pakistan is now known as Pakistan.

The West Pakistan ruled over whole Pakistan from 1947 to 1971 with a mixture of good and bad flavor. The mother tongue of West Pakistan was 'Urdu' and the mother tongue of East Pakistan was 'Bangla'. Pakistan government declared 'Urdu' as the state language of Pakistan but the people of East Pakistan did not accept it, because the majority people of Pakistan used to speak at that time 'Bangla' language. So, the Bangladeshi people (East Pakistan) demanded from the Pakistan government that the state language of Pakistan would be two languages: Urdu and Bangla, but the Pakistan government did not accept it.

Other problems were that there was discrimination in developing the country. There were more development in West Pakistan and less development in East Pakistan. The Worst situation happened in 1970 when in National Election AL got majority seats in the National Election of Pakistan. As a result, AL wanted to form the central government but the Pakistani army and the chief political leader of West Pakistan Zulfikar Ali Vutto did not allow Sheikh Mujib (the leader of AL in East Pakistan) to form the central government of Pakistan. Hence, a serious impasse and chaos arose in the politics of Pakistan. These matters together with other matters led to the separation of Bangladesh from Pakistan.

As stated earlier that Bangladesh Jamaat-e-Islami (Jamaat) opposed separation of Pakistan along with other five political parties. They opposed the separation of Bangladesh in a peaceful manner and they were not involved in killing, rape and arson against the freedom fighters of Bangladesh or any other people who wanted to separate Bangladesh from Pakistan. After separation of Bangladesh in 1971, AL formed the government in Bangladesh and made International War Crimes (Tribunal) Act 1973 to try identified war criminals from Pakistani soldiers who surrendered and were arrested. In 1973, Sheikh Mujibur Rahman, the first President of Bangladesh identified total 195 war criminals after investigation but all of them were Pakistani army officers, no Jamaat leaders or its supporters were among them (Abu Rawsab, 13 February 2010).

At that time Awami League (AL) government also arrested more than 100,000 people for the allegation of assisting Pakistani army to commit war crimes under the Bangladesh Collaborators (Special Tribunal Act) 1972. After investigation, charge sheets were submitted only against 2,848 people and criminal offence was proven only against 752 accused and they were punished for different terms of imprisonment. No Jamaat leader or its supporter's name was in the list of the guilty people (See, Abu Rawsab, 13 February 2010; RTNN, 23 March 2010; Daily Sangram, 1 April 2010). So, it is a settled issue in 1973 that no Jamaat leaders were involved in any war crimes or crimes against humanity and it is historically proven from the investigation and trial result in 1973. For this reason, probably AL did not take any initiative to try Jamaat leaders for war crimes during their 9 years rule from 1972-1975 and 1996-2001. During this time even AL worked together and had joint meetings and press conferences with Jamaat leaders and the photographs of those joint meetings and press conferences are still available.

The present AL government seriously oppressing Jamaat leaders and its supporters. More than 4000 Jamaat and Shibir leaders and their supporters had been arrested and detained under false cases. They were seriously oppressed in custody of police department since the last week of February 2010 (Abu Rawsab, 13 February, 2010; Daily Sangram, 11 April, 2010). It is important to mention here that Jamaat is a democratic political party and it is widely known to the people of Bangladesh. From the independence of Bangladesh, it is participating in all national and local elections peacefully and does not practice hostile politics. That's why the people of 
Bangladesh are very pleased with Jamaat and its supporters are increasing day by day. In 1971 it had only 100,000 supporters and now it has 10,000000 (ten million) supporters in Bangladesh.

AL feels jealous of Jamaat for its wide support among the people. So, it has started making conspiracy against Jamaat to destroy the party. Last month (March 2010) the State Minister of Bangladesh openly asked the police department to eradicate Jamaat and its branch organization Shibir. Such announcement by the Home Minister is known to the people of Bangladesh as it was published in the daily newspapers in the first week of March 2010 (Daily Sangram, 3 March 2010; Daily Nayadiganto, 6 March 2010). The Home Minister is a respected person; she cannot order the police department to eradicate an well-established political party members who are doing democratic politics in a peaceful and lawful way. The statement of the Home Minister proves the human nature of the Minister and the character of AL party as a whole.

Awami League (AL) government has right to try war criminals even after 39 years but the question is raised by different groups of intellectuals and people of Bangladesh that why they did not try the war criminals during 1972-1975 and 1996-2001 when they were in power? It is said that AL's main target is to hang top Jamaat leaders as openly declared by some of the Ministers of AL, but why they did not hang them during previous 9 years when they were in power and at that time it could be easier to gather evidence against them. After 39 years a lot of key evidence is lost and as stated by many legal scholars and diplomats that it would be very difficult even impossible for AL now to prove war crimes case after 39 years as adequate evidence would not be found to prove the case beyond reasonable doubt (See, Hossain, 16 May 2009; Daily Sangram, 28 March 2010).

AL government is not allowing Jamaat leades to go out of the country without any good reason. They are stopped at the airport and harassed and sent back home saying that you are not allowed to go abroad. Airport authority says, it is government's order, you can't go abroad. Thus, AL government is violating democratic and fundamental rights enshrined in the Constitution of Bangladesh that every citizen has right to travel outside the country if he is not involved in any criminal offence. AL cannot stop Jamaat leaders to go abroad unless they have good reason to stop them. AL government says Jamaat leaders were involved in war crimes 39 years ago, but government has no evidence to prove that and Jamaat leaders have been frequently denying the demand of AL government for the last 39 years saying that they did not commit any war crimes in 1971.

Bangladesh is suffering from acute poverty and unemployment. Millions of poor people are starving everyday and suffering from mal-nutrition. The weather is very hot in Bangladesh from April to September every year $\left(35^{\circ} \mathrm{C}\right.$ to $40^{\circ} \mathrm{C}$ temperature) but every day $10-16$ hours there were no electricity in the whole country since April 2010. So, people are suffering from severe hotness and industries in the country cannot produce goods for 10-16 hours every day for heavy load-shedding in the country. So, the GDP growth in the industry sector is seriously jeopardized. Millions of people in Dhaka city (the capital city) are not getting even minimum amount of water for the last two months (June and July) and the situation is continuing to be the worst. AL government has totally failed to solve electricity and water shortage problem. Similarly, the people of Bangladesh are suffering from acute gas shortage. These are priority issues at present to put emphasis upon and AL government should solve these problems as soon as possible but it is indifferent on these crucial national issues. People of Bangladesh can only hear from their mouth joyfully that top Jamaat leaders will be hanged for war crimes, although they do not have adequate evidence to justify their claim. So, hanging Jamaat leaders for no offence is greater importance than solving electricity, gas, water and unemployment problem to AL government. A reasonable person will comment on such a behavior of the AL government as blood sucking autocratic government.

As said earlier AL has all rights to try Jamaat leaders for war crimes but the trial must be fair and credible under an impartial Tribunal. If the trial is motivated to revenge against the opposition parties and to make them weak, that is not acceptable in democracy and it is a clear violation of fundamental rights of opposition parties as citizens of the country (Abdul Kader, Daily Sangram 25 March 2010). Three judges have been appointed in the War Crimes Tribunal but they are all hardcore supporters of AL government. The investigators and prosecutors are also hardcore supporters of AL government. So, there is no chance of free, fair and impartial trial of Jamaat leaders (Sirajul Islam and Saidul Islam; Abu Rawsab, 29 May 2010). AL government is undertaking to try Jamaat leaders for criminal offences only to cause great harm on this political party because a large number of people are becoming its supporters every month. As said earlier, currently it has 10 million supporters in Bangladesh. So, AL government is afraid of this party and it is desperate to take revenge against Jamaat by wiping out the top leaders of Jamaat. But such a political stand of AL government will not be acceptable to the world community. The world community will show anger against AL government for their inhumanly cruel acts.

The people of Bangladesh is now asking an important question to AL government "can the war crimes trial after 39 years of independence, bring development and prosperity for the poor people in Bangladesh?" AL 
government needs to answer this question. If they can prove that the trial will bring development and prosperity for the 140 million poor people in Bangladesh, then AL government should continue the war crimes trial. If they fail to answer this question positively, then they should abandon the war crimes trial and instead should exert adequate efforts for the development of the country by undertaking urgent plans to solve electricity, water, gas, unemployment problem, controlling price hike of daily necessary things etc.

Now let us see some recent reports on Bangladesh from daily newspapers and from the statements of renowned politicians and intellectuals related to human rights violation in Bangladesh. Bangladesh is losing its labour market in the world and the labour market is being occupied by Nepal and India in Muslim countries. This is a great loss for Bangladesh which has 50\% unemployed people. Bangladesh was earning a lot of foreign money through their additional labour force working in different countries such as in Malaysia, in the Middle East etc. Failure of AL government to preserve labour market in foreign countries will be very damaging for the economy of the country and it will increase the unemployment rate in the country. According to intellectuals of Bangladesh, this failure of AL government is due to its failure of diplomatic policy to keep good relation with other countries (Daily Sangram, 11 April, 2010).

The Law Minister after coming back from the US visit in the last week of March 2010 said we are not going to try the opponent party members for war crimes but for crimes against humanity. This is because the main war criminals of 195 Pakistani soldiers were given amnesty in 1973. So, by giving amnesty to main criminals, semi-criminals cannot be tried after 39 years in an international war crimes tribunal. That is why AL government has abandoned the trial of war criminals, according to the political analysts in Bangladesh (Daily Sangram, 11 April, 2010).

During AL rule from 1972-1975, AL government with the help of Rakhkhi Bahini killed more than 3000 intellectuals and scholars who opposed the oppressive rule of $\mathrm{AL}$ government and protested against the formation of BAKSAL. The people of Bangladesh thinks that if AL government wants to try 1971 war criminals, then they must also try AL leaders and Rakhkhi Bahini members who were involved in killing more than 3000 people during its oppressive rule between 1972-1975. AL government cannot escape this criminal liability of its members and leaders (Jalal Uddin, 5 February, 2009).

In February 2009, more than 60 top army officers have been killed in Pilkhana BDR headquarter. These army officers were highly trained and were extremely patriotic, the people of Bangladesh know about it. According to the investigation report of Bangladesh Army, AL government was directly involved in this killing of top army officers. The dead bodies of the beloved and patriotic army officers were thrown in the drains and the culprits were allowed to escape easily from the massacre place by AL government. The wives of killed army officers were raped and molested by the rebel BDRs. AL has killed extra-judicially more than 50 BDR members in police custody in March 2010 who were involved in the army massacre. This is to destroy the evidence that AL government was involved in this inhuman killing of the honorable army officers. Until today AL government is trying to bypass the trial of the real criminals of this massacre who were AL leaders.

From these two incidence, i) killing of more than 3000 people by Rakhkhi Bahini and ii) killing of 60 top patriotic army officers in Pilkhana BDR headquarter, Dhaka and other 50 BDR men in police custody, prove that $\mathrm{AL}$ government is terrorist in nature. They have no quality and ability to run and develop the country. Recently they have signed many international treaties with India against the national interest of Bangladesh and for the interest of India. To implement these treaties AL government has borrowed 1billion US\$ with high rate interest from an Indian bank located in India and the whole money would be spent to make roads between India and Bangladesh for the use of India, to upgrade Chittagong and Mongla seaports for the use of India without any payment to Bangladesh. On the other hand, Bangladesh has to pay high rate interest and the huge capital back to India. A patriotic government of an independent country cannot make such agreements with India which totally go against national interest and national security.

Awami Jubo League and Satro League and the police department are busy to eradicate Jamaat and Shibir supporters from Bangladesh. They are oppressing, beating and killing of Jamaat and Shibir supporters all over the country. As mentioned above, more than 4000 Jamaat and Shirbir supporters have been arrested from March to July 2010 from all over the country and are being oppressed in remand and detention without any offence been proven against them (Daily Sangram, 11 April 2010). Jubo League and Satro League (AL branch organizations) are busy with tender terrorism. Recently some AL ministers, Jubo League and Satro League members committed rape with girl students from different colleges and universities in Dhaka the capital city of Bangladesh by force including Eden College in Dhaka, Bangladesh (News World, New York, 12 April 2010). AL government did not take any action against these criminal ministers and MPs. Jubo League and Satro League 
(AL branch organizations) members are taking all government tenders by force and threat. So, tenders are not allocated to qualified builders and businessmen in accordance with the law of the country. (Daily Sangram, 11 April, 2010).

Law Deputy Minister, Kamrul Islam on 10 April 2010 said AL government will take over control of Islami Bank and Ibni Sina Trust in Bangladesh, the reason is that they are controlled by opposition party Jamaat Islam. These two organizations are public companies and they are complying with Bangladeshi laws including the Companies Act (Bangladesh) and they are not involved in any illegal activities. Intellectuals opine that the Law Deputy Minister's statement to take over the Islami Bank and Ibni Sina Trust amounts to terrorism, misuse of government power and acting against law (Daily Sangram, 11 April, 2010).

As stated earlier, AL government has been failed to provide adequate electricity, gas, water to the people; has been failed to control price hike of daily necessary things and the law and order situation has been very alarming. The people of Bangladesh are very displeased with AL government. AL government has brought down the war crimes trial issue after 39 years just to hide their failure to solve these important crises. This opinion has been expressed by the former Minister Dr. Khondoker Mosharraf Hossain (Daily Sangram, 11 April, 2010). Trial of war criminals after 39 years especially when the main 195 war criminals have been pardoned in 1973, is not an important issue at present crisis situation in Bangladesh now. This is the opinion of many scholars, politicians and intellectuals of Bangladesh (See, Barrister Jamiruddin, Daily Sangram, 28 March 2010).

AL government is giving promotions in different positions to its own party people disregarding the senior and qualified officers in police and other departments. Benojir Ahmed has been promoted to DIG of police leaping 27 senior police officers who were above Mr. Benojir Ahmed in ranking. So, AL is politicizing the administration by appointing and giving promotion to AL hardcore supporters in police, army, ministries, judiciary and other administrative departments (Daily Sangram, 11 April, 2010).

On 7 April, 2010, the Secretary General of Jamaat and former Minister, Ali Ahsan Muhammad Mujahid had assembly with people in Satkhira. AL government did not allow him to go to Satkhira. He was stopped by police in Jero Point, Khulna; one of the police officers tried to break his car glass and tried to open his car door by force at 11:45 pm at night and told him to go back to Dhaka saying that it is the instruction of the government. He took shelter in Al-Faruk Society in Khulna to secure himself and other Jamaat leaders with him but at night around 2:00 AM, 50 to 60 Jubo League and Satro League workers attacked the Society with heavy rod and stick to kill Mr. Mujahid. Police refused to give any security to Mr. Mujahid and asked him to go back to Dhaka. As the situation was very risky for him, he decided to come back to his own house in Faridpur District to stay that night.

AL government also declared section 144 of the Criminal Procedure Code and cancelled the prior permission given to organize the assembly of Jamaat in Razzak Park at Satkhira where Mr. Mujahid supposed to address in front of thousands of people (Daily Sangram, 9 April 2010). This incidence is one of the hundred examples that AL government is violating democratic and fundamental rights of opposition parties to organize political assembly peacefully. This right has been guaranteed by the Constitution of Bangladesh. Attacking on the former Minister Mujahid by AL supporters on 7 April 2010 at night at 2:00 am in Khulna amounts to an attempt to murder by the government party members.

The President of National Communist Party (JSD) and the first independence flag lifter of Bangladesh, respected A.S.M. Abdur Rob has said that I have no evidence that Matiur Rahman Nijami (the Jamaat President), Secretary General of Jamaat, Ali Ahsan Muhammad Mujahid and Jamaat Vice-President, Delwar Hossain Saydi had committed any war crimes. These people are top leaders of Jamaat whom AL government wants to hang without any evidence of war crimes. A.S.M. Rob said that he wants trial of war crimes but it must not be for political gain and to oppress opposition parties. He also said that if wrong persons' names are included in the war crimes list, the consequence will be very dangerous (Daily Sangram, 9 April, 2010).

Recently a seminar was held by some U.S. citizens on 12 April, 2010 in York College auditorium of New York City in the U.S. against human rights violation in Bangladesh by the present AL regime. The speakers said that AL government has declared some names as war criminals whose ages were between 4-8 years in 1971; how could they fought against the freedom fighters in Bangladesh? So, labeling these young Jamaat leaders as war criminals is clearly ridiculous. According to speakers in the seminar, by declaring death penalty to some of the top Jamaat leaders before trial starts, is a non-sense decision or comment by some of the AL ministers and it amounts to serious violation of human and democratic rights of opposition political leaders of Bangladesh and it also amounts to criminal defamatory statement by the AL government ministers (News World, New York, 13 April, 2010). 
The speakers in this seminar stated that the International War Crimes (Tribunal) Act 1973 (the 1973 Act) has excluded the Constitution of Bangladesh, Evidence Act 1872 and Code of Criminal Procedure Code 1898. These procedural laws to protect human and legal rights of the accused have been made inapplicable in the trial process under section 23 of the 1973 Act. The intention of such exclusion of procedural safeguard of the accused persons is mala fide and revengeful. The intention of $\mathrm{AL}$ government is to pass death sentence for top Jamaat leaders (which is one of the largest political party in Bangladesh) without giving them any right to appeal against the decision of the Tribunal.

It is to be mentioned that The 1973 Tribuanal has been given power and jurisdiction equivalent to the High Court Division which is an exception in Bangladesh, because in Bangladesh when any Tribunal is formed it is ranked below the High Court Division, so that the guilty person can appeal to the High Court Division. Here, there is bad political motive of AL government that is to deprive the guilty persons in the Tribunal the fundamental constitutional right to appeal to the High Court Division. As the Evidence Act will not be applicable under section 23 of the 1973 Act, hearsay evidence and newspaper false allegation can be taken into consideration to find the Jamaat leaders guilty of war crimes or crimes against humanity (Newsworld, New York, 13 April, 2010). Hence, the intention of AL government is to hang the top Jamaat leaders will be successful and it would be inhuman and total violation of human and democratic rights of the accused.

The speakers in the seminar on human rights violation in the U.S. as mentioned above said that the present AL government can be compared with 1971 Baksali one party oppressive rule of AL government. So, all the patriotic people of Bangladesh should protest against the autocratic rule of AL government. The New York State Parliament Member, who was elected from the Queens of New York City expressed his great concern on the violation of human and democratic rights in Bangladesh and asked the Bangladeshi people to be united against the AL government to protest against its human rights violation against opposition parties. New York State Parliament Member, Mr. Selix Doblew Ortiz attended the seminar and he promised to table a proposal in the New York State Parliament against the ongoing violation of human rights in Bangladesh.

\section{Conclusion}

In this situation the people of Bangladesh think that $\mathrm{AL}$ government is heading to the wrong direction to revenge against opposition political parties especially Bangladesh Jamaat Islam. They are violating democratic and fundamental rights of opposition parties. The people of Bangladesh has given more than two-thirds majority seats to AL in the Parliament with the hope that it will undertake development projects to create new jobs to the unemployed people, to solve electricity, water and gas problem, to stop corruption and extortion of money by elite groups from businessmen, to give security of life of people by improving law and order situation in the country etc. But AL government is really making the people hopeless and disappointed. They are now heading to only one direction that is how to hang the top Jamaat leaders in the shortest time possible without any legal and valid grounds.

Since the independence of Bangladesh in 1971, it has failed to develop a durable and amicable democratic system in the country. There is evidence that AL government killed the respected Speaker of the Parliament in East Pakistan in the Parliament House during Parliament Session. It is said by Bangladesh intellectuals that during AL rule between 1972 to 1975, they killed more than 40,000 people in Bangladesh. They are widely known to the people of Bangladesh as the killer and autocratic party. They kill opposition political party leaders whenever they oppose or protest against any AL government policy which goes against public interest and national security and independence of Bangladesh. How can they establish durable and tolerable democracy in Bangladesh? From the date of birth of Bangadesh, AL is fighting with other political party leaders and supporters. Recently on 10 October 2010, AL members killed an elected sub-district chairman belong to an opposition party BNP on the street in front of people in broad day light (The Daily Sangram, The Daily Naya Diganto, 11 October, 2010). AL is adopting hostile political philosophy which is dividing the people into different parties. If they could unite the nation by undertaking a long-term development vision for Bangladesh, we are sure that AL could obtain great appreciation from people and could take the country ahead of development. Such a policy is very much desired in Bangladesh at the present time.

$\mathrm{AL}$ as an oldest political party in Bangladesh who were involved in liberation movement of Bangladesh against Pakistan in 1971, always practices 'one country, one party policy'. So, AL does not practice democracy in the country even in the party. It never holds election for the position of the President of the party. Sheikh Hasina is the President of AL since 1975 after the assassination of his father Sheikh Mujibur Rahman, the first President of Bangladesh. They think that other political parties have no right to do politics in Bangladesh. That is why in 1975, the first President Sheikh Mujibur Rahman banned all the political parties in Bangladesh in an autocratic 
way and formed only one party called BAKSAL and asked all people to be its members and supporters. He cancelled the licenses of all daily newspapers except a few which were fully controlled by him. These newspapers never wrote anything against the President and his party. He formed Rakhkhi Bahini (Security Force) and used this armed force to kill extra-judicially more than 3000 people just after independence of Bangladesh who were scholars, intellectuals, professionals, political leaders etc. because they opposed the 'one party autocratic rule' of President Sheikh Mujibur Rahman.

AL has come to power by the help of the Army backed Caretaker Government in January 2009 and it is treating with other political parties in the same way as Sheikh Mujibur Rahman behaved with opposition parties between 1972-1975. It is to be noted that Sheikh Mujibur Raham was assassinated by the Army of Bangladesh for his autocratic and oppressive rule. It is also important to mention that the present Prime Minister of AL Sheikh Hasina is the daughter of Sheikh Mujibur Rahman who was the first President of Bangladesh in 1973 after separation of Bangladesh from Pakistan. The present AL government is killing and beating people including opposition political party leaders, not allowing opposition parties to have political assembly, not allowing Jamaat leaders to go abroad without any good reason, attacking and killing opposition political party leaders and supporters and not allowing them to protest against the oppressive and undemocratic practices of the present government. The people of Bangladesh are now passing very tragic and repressive time. People do not have enough food to eat and they are suffering from acute shortage of water and electricity in a very hot weather since April 2010. At present more than 50\% people are unemployed, more than $60 \%$ people are illiterate. Government so far is not doing anything effective work to solve these problems. Political analysts think that this government has no intention to develop the country and to solve its problem. Its only intention is to attack, oppress and kill opposition political party members and to establish one party autocratic rule.

\section{References}

A.S.M Rob. (2010). I have no evidence that Nijami, Mujahid and Saydi had committed any war crimes. [Online] Available: publication-date-2010-04-09. http://www.dailysangramcom/archive/news details.php?news id=28833\&

Abu Rawsab. (2010). Are Jamaat-Shibir Terrorists or Victims of Terrorism. The Daily Sonar Bangladesh (online). [Online] Available: www.sonarbangladesh.com/print.php?id=1993.

Abu Rawsab. (2010). Ten reasons why the war crime tribunal is bound to be kangaroo court. Save Bangladesh, 29 May 2010. [Online] Available: http://www.savebd.com/articles/ten-reasons-why-the-war-crime-tribunal-is-bound-to-be-a kangaroo-court/.

Bangladesh Collaborators (Special Tribunal) Act 1972.

Barrister Jamiruddin. (2010). Barrister Jamiruddin Sarker to the journalists: to try war criminals with an intention to weaken the opposition parties, would not be acceptable and credible. The Daily Sangram and The Daily New Nation, 28 March 2010. [Online] Available: http://www.dailysangram.com/news_details.php? news_id=28071.

Code of Criminal Procedure Code 1898 (Bangladesh).

Daily Naya Diganta. (2010). Labour export is decreasing for Bangladesh: India and Nepal is capturing the labour market in the Muslim world. The Daily Naya Diganta and The Daily Sangram, 11 April, 2010. [Online] Available: http://www.dailysangram.com/

Daily Sangram. (2010). Benojir Ahmed has been appointed as DIG of police after leaping 27 senior police officers. The Daily Naya Diganta and The Daily Sangram, 11 April, 2010. [Online] Available: http://www.dailysangram.com/.

Daily Sangram. (2010). Jubo League, Satro League and Police are busy for eradicating Jamaat-Shibir, The Daily New Age and The Daily Sangram, 11 April, 2010. [Online] Available: http:www.dailysangram.com/news_details.

Daily Sangram. (2010). Tender Terrorism by Jubo League and Satro League. The Daily Naya Diganta and The Daily Sangram, 11 April, 2010. [Online] Available: http://www. dailysangram.com/news_details. php?news_id +28958 .

Daily Star. (2010). Law Deputy Minister's statement to take over Islami Bank and Ibne Sina Trust by AL government is an irresponsible statement. The Daily Star and The Daily Sangram, 11 April, 2010. [Online] Available: http://www.dailysangram.com/.

Evidence Act 1872 (Bangladesh). 
Hossain, Emran. (2009). The Daily Star Interviews Amnesty International (AI) Asia Pacific Program Director Sam Zarifi. The Daily Star, 16 May 2009. [Online] Available: http://www. thedailystar.net/newsDesign/story-details.php?nid=208.

Jalal Uddin. (2009). Not Just Collaborators, Baksalite and the Rakhkhi-Bahini Elements Too. News Forum Bangladesh, 5 February, 2009. [Online] Available: http://www. Bangladesh-web.com/view.php? hidRecord= 186352.

Kader, Abdul. (2010). Bengali Hero Kader Siddiqui in TV Interview: AL government is not ready for war crimes trial; fair and international standard trial needed. The Daily Sangram and The Daily Naya Diganto, 25 March, 2010. [Online] Available: http://www.dailysangram.com/news_details.php? news_id=27905.

Khandoker Musharraf. (2010). AL government is indifferent to solve serious problems of people because they were not elected by people. The Daily Sangram and The Daily Star, 11 April, 2010. [Online] Available: http://www.dailysangram.com/news_details.php?news_id=28960

Mujahid. (2010). Statement of Ali Ahsan Muhammad Mujahid in Press Conference: AL government is staging imaginary war crimes trial drama being failed to face Jamaat politically. The Daily Sangram, 1 April 2010. [Online] Available: http://www.dailysangram.com/news_details.php?news_id=28318. It is to be noted that Mr. Ali Ahsan Muhammad Mujahid is the Secretary General of Bangladesh Jamaat-e-Islami (Jamaat) and was former Welfare Minister of Bangladesh.

Mujahid. (2010). Ali Ahsan M. Mujahid in Press briefing: The failure of AL government to provide security of life and property to people, will damage the stability of the country. The Daily Sangram and The Daily $\begin{array}{llllll}\text { Amardesh, } & 9 & \text { April, } & 2010 . & \text { [Online] } & \text { Available: } \\ \text { http://www. }\end{array}$ dailysangram.com/archive/news_details.php?news_id=28829publication_date=2010-04-09.

News World, New York. (2010). Human Rights Seminar in the U.S.: The War Crimes Tribunal in Bangladesh is a Drama. The Daily Amardesh, 13 April, 2010. [Online] Available: http://www.amardeshonline.com/pages/details/2010/04/13/27320.

RTNN. (2010). The concern of AMT with law and order situation in Bangladesh, memorandum to Hillary. The Daily RTNN, 23 March 2010. [Online] Available: http://www.rtnn.net/details.php?id=22885 \&p=1\&s=9.

Serajul Islam and Saidul Islam. (2010). War Crime Tribunal in Bangladesh: A Contested Move. [Online] Available: http://www.sonarbangladesh.com/article.php?ID=2296.

The International War Crimes (Tribunal) Act 1973 (Bangladesh). 